\title{
Left Ventricular Mass Regression following Implantation of St. Jude Medical Trifecta Aortic Bioprosthesis
}

\author{
JA Chacko, J Edlin, AH Sepehripour, SG Ambekar, KS Lall \\ From World Society of Cardiothoracic Surgeons 25th Anniversary Congress, Edinburgh \\ Edinburgh, UK. 19-22 September 2015
}

\section{Background/Introduction}

The St. Jude Medical Trifecta aortic supra-annular bioprosthesis is regarded as the next generation in pericardial stented tissue valves. The unique design of tissue leaflets attached to the exterior of the valve stent provides unrivalled in-vivo mean gradients and haemodynamics.

\section{Aims/Objectives}

The aim of this prospective study was to evaluate midterm left ventricular (LV) mass regression following implantation for aortic stenosis.

\section{Method}

One hundred and seventy two consecutive patients undergoing aortic valve replacement using the St. Jude Medical Trifecta valve at a single UK centre over a 48-month period were included in this study. Patients undergoing concomitant cardiac procedures were included. All implanted valves were 19, 21, 23, 25, 27 \& $29 \mathrm{~mm}$ in size. Patients underwent both pre-operative and post-operative transthoracic echocardiography. Two-dimensional measurements of the left ventricle were used to calculate LV mass using the Devereux equation.

\section{Results}

30 patients had the adequate 2-dimensional left ventricular measurements recorded to calculate both pre- and postoperative left ventricular mass. Valve Sizes were $21 \mathrm{~mm}$ $(\mathrm{n}=7), 23 \mathrm{~mm}(\mathrm{n}=15), 25 \mathrm{~mm}(\mathrm{n}=6)$ and $27 \mathrm{~mm}$ $(\mathrm{n}=2)$. Overall absolute left ventricular mass regression was $18.1 \% \pm 23.8 \%$. Mean preoperative LV mass was $247.8 \mathrm{~g}$ $\pm 102.5 \mathrm{~g}$ and mean postoperative LV mass was $200.7 \pm$ 74.1g. Regression of LV Mass Index was $-30.66 \mathrm{~g} / \mathrm{m} 2$.

\section{Discussion/Conclusion}

Utilising available 2-D Measurements in this group we observe regression of LV mass \& LV Mass Index post aortic valve replacement with the Trifecta bioprosthetic valve. However, further consistent 2-D measurements are required across the cohort to establish this relationship.

Published: 16 December 2015

doi:10.1186/1749-8090-10-S1-A308

Cite this article as: Chacko et al:: Left Ventricular Mass Regression

following Implantation of St. Jude Medical Trifecta Aortic

Bioprosthesis. Journal of Cardiothoracic Surgery 2015 10(Suppl 1):A308.
Submit your next manuscript to BioMed Central and take full advantage of:

- Convenient online submission

- Thorough peer review

- No space constraints or color figure charges

- Immediate publication on acceptance

- Inclusion in PubMed, CAS, Scopus and Google Scholar

- Research which is freely available for redistribution
() Biomed Central

\section{St.Batholomew's Hospital, London,}

(C) 2015 Chacko et al. This is an Open Access article distributed under the terms of the Creative Commons Attribution License (http:// Biomed Central creativecommons.org/licenses/by/4.0), which permits unrestricted use, distribution, and reproduction in any medium, provided the original work is properly cited. The Creative Commons Public Domain Dedication waiver (http://creativecommons.org/publicdomain/ zero/1.0/) applies to the data made available in this article, unless otherwise stated. 